\title{
Strategi kemas ulang informasi untuk peningkatan pelayanan perpustakaan di era new normal
}

\author{
Wahid Nashihuddin \\ Lembaga Ilmu Pengetahuan Indonesia \\ Jl. Jenderal Gatot Subroto 10, Kuningan Baru, Jakarta, 12710 \\ E-mail: wahi002@lipi.go.id
}

Received: July 2020; Accepted: May 2021; Published: June 2021

\begin{abstract}
Information repackaging is one of the library's efforts to meet users' information needs in the new normal era. Libraries need to prepare various strategies in providing repackaging products as a library service innovation. This research aimed to describe various aspects and stages of library strategy design in information repackaging in the New normal era. The research used a qualitative approach through literature studies research methods. The results showed that libraries and librarians in the new normal era needed to pay attention to various aspects and stages in designing a digital information repackaging strategy. Aspects of the information repackaging strategy include determining the source of packaging information, types of information repackaging products, and information repackaging methods. Libraries carry out information repackaging strategies by making information repackaging the library's flagship program and the librarian's main job, understanding the information behavior of the library's native digital users, disseminating digital information packages through social media and collaborative networks, changing the librarian's role into social librarians and public knowledge and implementing a Marketing and Public Relations (MPR) strategy to disseminate information repackaged products to users. The head of the library plays an important role in supporting librarians in carrying out information repackging activities. This research concludes that the librarian strategy of repacking information in the new normal era is needed to improve library services that are more creative, interactive, and innovative, in accordance with the user's information needs.
\end{abstract}

Keywords: Information repackaging; Library strategy; Information management; Librarian roles; New normal

\begin{abstract}
Abstrak
Kemas ulang informasi adalah salah satu upaya perpustakaan untuk memenuhi kebutuhan informasi pengguna di era new normal. Perpustakaan perlu menyiapkan berbagai strategi dalam penyediaan produk kemas ulang informasi sebagai inovasi pelayanan perpustakaan. Penelitian ini bertujuan untuk mendeskripsikan strategi kemas ulang informasi perpustakaan di era new normal. Penelitian ini menggunakan pendekatan kualitatif dengan metode penelitian studi literatur. Hasil penelitian menunjukkan bahwa perpustakaan dan pustakawan di era new normal perlu memperhatikan strategi kemas ulang melalui aspek strategi dan perancangan strategi pengemasan ulang informasi digital. Aspek strategi pengemasan ulang informasi mencakup penetapan sumber informasi kemasan, jenis produk kemas ulang informasi, dan metode pengemasan ulang informasi. Perancangan strategi pengemasan ulang informasi dilakukan perpustakaan melalui kemas ulang informasi sebagai program unggulan perpustakaan dan pekerjaan utama pustakawan, memahami perilaku informasi pengguna digital native perpustakaan, melakukan diseminasi paket informasi digital melalui media sosial dan jaringan kerja sama, merubah peran pustakawan sebagai social librarian dan public knowledge, dan menerapkan strategi Marketing and Public Relation (MPR) untuk diseminasi produk kemas ulang informasi ke pengguna. Kepala perpustakaan berperan penting mendukung pustakawan dalam melakukan kegiatan kemas ulang informasi. Simpulan penelitian ialah strategi pustakawan dalam kemas ulang informasi di era new normal sangat diperlukan untuk meningkatkan pelayanan perpustakaan yang kreatif, interaktif, dan inovatif, sesuai kebutuhan informasi pengguna.
\end{abstract}

Kata kunci: Kemas ulang informasi; Strategi perpustakaan; Pengelolaan informasi; Peran pustakawan; Kenormalan baru 


\section{PENDAHULUAN}

Kehidupan masyarakat Indonesia mengalami perubahan yang sangat besar sejak pandemi Coronavirus Disease (Covid19) melanda sejak awal Maret 2020. Terlebih lagi, Pemerintah Indonesia menetapkan status kehidupan new normal sejak Mei 2020 hingga sekarang. Era new normal berdampak pada kebijakan akses pelayanan informasi di perpustakaan yang awalnya tatap muka berubah digital (online). Kondisi tersebut menyebabkan perpustakaan melakukan driving forces, yaitu tren yang secara alami terjadi. Driving forces apabila dimanfaatkan secara baik akan berubah sebagai kekuatan yang dominan dan memaksa masyarakat untuk berubah (Khoir, 2018). Maka, driving forces sebagai kunci perubahan dalam tranformasi pelayanan perpustakaan dalam kebiasan baru berupa tindakan tegas kepada pemustaka untuk mematuhi protokol kesehatan yang ditetapkan perpustakaan.

Era new normal menyebabkan perpustakaan mengubah kebijakan pelayanan informasi berdasarkan protokol kesehatan. Untuk itu, perpustakaan perlu mengoptimalkan sumber daya informasi dan siap menyambut era new normal untuk memenuhi kebutuhan informasi pengguna (Rodiyah \& Indrakasih, 2020). Salah satunya melalui pelayanan pengemasan ulang informasi (information repackaging).

Bello and Ojjo (2018) mengatakan bahwa pengemasan ulang informasi merupakan pelayanan yang sangat dibutuhkan perpustakaan. Pelayanan kemas ulang informasi dapat dikelola perpustakaan berdasarkan kebijakan struktur organisasi atau kebutuhan informasi pengguna. Kegiatan kemas ulang informasi sebagai pelayanan utama perpustakaan dan tidak lagi sebagai pekerjaan rutin pustakawan.

Pengemasan ulang informasi adalah pelayanan khusus yang melibatkan proses pengumpulan, restrukturisasi, format ulang, pengorganisasian, dan konsolidasi informasi yang tersedia dalam bentuk berbagai sumber untuk kepentingan kelompok yang ditetapkan sasarannya secara khusus (Radhakrishnan \& Francis, 2017). Proses pengemasan ulang informasi menurut Okunade (2015), di antaranya (1) menetapkan target pengguna, identifikasi kebutuhan informasi pengguna dengan penilaian (survei), (3) seleksi format informasi, (4) seleksi channel media (publikasi dan promosi), (5) menyediakan umpan balik (feedback) dari pengguna, (5) evaluasi produk kemas ulang informasi (konten, format, dan pemanfaatannya). Dongardive (2013) menjelaskan bahwa pengemasan ulang informasi melalui berbagai tahapan, di antaranya proses seleksi, analisis, dan konsolidasi informasi dalam bentuk yang lebih tepat sehingga dapat digunakan pemustaka.

Adapun manfaat dari kemas ulang informasi menambah nilai ekonomi bagi institusi penyedia informasi dan perpustakaan. Perpustakaan perlu menyiapkan berbagai strategi dalam penyediaan produk kemas ulang informasi yang tepat. Hal ini agar konten informasi mudah dicari dan ditemukan pemustaka, serta memberikan manfaat yang besar bagi perpustakaan di masa depan (Dongardive, 2013).

Pebrianti (2015) and Wulansari (2017) memberikan pendapatnya bahwa kegiatan kemas ulang informasi di perpustakaan memiliki tujuan untuk menarik pengguna dalam menemukan 
dan menggunakan informasi yang spesifik. Selain itu, kemas ulang informasi dapat mempercepat akses informasi, menekan biaya akses konten informasi, dan mengoptimalkan layanan perpustakaan sesuai kebutuhan informasi pengguna. Adapun fungsi dari kemas ulang informasi di perpustakaan memiliki berbagai fungsi, di antaranya sebagai alat penyimpan informasi, penyortir sistematis dan selektif informasi, sarana pengiriman dan transmisi informasi yang luas, alat terjemahan, media diseminasi hasil penelitian, dan sarana promosi informasi yang relevan (Dongardive, 2013; Nashihuddin \& Tupan, 2016; Wulansari, 2017).

Produk kemas ulang (berupa CD/DVD atau database online) dapat digunakan sebagai alat penyimpan informasi, penyimpanan dan pendokumentasian berbagai informasi mutakhir (karya populer dan karya penelitian) yang dapat digunakan pengguna dalam pengembangan iptek dan proses pembelajaran. Penyediaan sumber informasi digital melalui produk kemas ulang informasi yang relevan sesuai kebutuhan informasi pengguna dapat meningkatkan kualitas pelayanan sebuah perpustakaan. Selain itu, kegiatan kemas ulang informasi pun berperan dalam peningkatan mutu pelayanan informasi perpustakaan dan lembaga dokumentasi dan informasi (Tupan \& Nashihuddin, 2015). Pelayanan kemas ulang informasi sebagai salah satu upaya perpustakaan dalam membantu pengguna menemukan informasi secara mudah dan cepat berdasarkan bidang tertentu (Rizkiyah, 2017). Pustakawan melalui teknologi informasi menunjang kemas ulang infomrasi sesuai kebutuhan pemustaka (Magfirah, 2019).
Secara prinsip, pembuat kemas ulang informasi harus memahami setiap produk informasi yang akan dihasilkan. Kebijakan perpustakaan dalam inovasi pengemasan ulang informasi sangat memengaruhi efektivitas pemanfaatan produk kemasan yang dihasilkan, baik format cetak atau digital. Sumber informasi kemas ulang informasi bahan cetak dan digital dapat berupa tulisan, foto, atau gambar (Muchlis, 2017).

Perpustakaan sebagai produsen produk kemas ulang informasi perlu memperhatikan beberapa hal. Ugwuogu (2015) menyebutkan di antaranya perpustakaan harus memperhatikan proses format ulang dan sintesis informasi mentah, penyediaan layanan konsultasi oleh spesialis informasi, dan program pelatihan untuk pengembangan keterampilan pemustaka dalam pengemasan informasi. Selain itu, perpustakaan pun harus memperhatikan teknik analisis informasi mentah, memperhatikan kecermatan dalam penerjemahan bahasa asli informasi ke bahasa lokal (lisan), komunikasi tim pembuat kemasan (diskusi), dan penggunaan alat/teknologi pengemasan ulang informasi.

Kegiatan kemas ulang informasi sebagai salah satu upaya perpustakaan dalam peningkatan kualitas pelayanan informasi misalnya pada Perpustakaan Hong Kong University of Science and Technology (HKUST) yang telah melakukan pengembangan koleksi e-book yang dilanggan melalui database Ebrary dan Willey, juga hasil konsorsium melalui database JSTOR. Pengembangan koleksi e-book melalui penyediaan akses informasi fulltext dan gratis berdasarkan sistem persetujuan dengan penerbit dan permintaan pemustaka perpustakaan 
(demand-driven acquisition) (Kwok, Chan, Cheung, \& Wong, 2014).

Kemas ulang informasi dapat diciptakan berdasarkan kreativitas pustakawan, bukan berdasarkan program unggulan perpustakaan dan permintaan informasi pengguna. Jika hal ini masih terjadi, produk kemas ulang informasi hanya akan digunakan sebagai dokumen arsip perpustakaan yang keberadaannya tidak akan memberikan manfaat bagi masyarakat. Untuk itu, permasalahan tersebut perlu segera diselesaikan perpustakaan melalui penetapan strategi pengelolaan kemas ulang informasi di perpustakaan.

Perpustakaan dan lembaga telah memiliki strategi tertentu dalam proses pengemasan ulang informasi. Hal ini dijelaskan beberapa peneliti dalam penelitian terdahulu. Pertama, penelitian Okoroma (2014) yang menjelaskan bahwa perpustakaan perlu melakukan inovasi dalam pengemasan informasi dengan memanfaatkan sumber daya informasi secara maksimal dengan biaya yang tidak besar. Perpustakaan harus mengidentifikasi kebutuhan pemustaka berdasarkan hasil evaluasi pemanfaatan sumber informasi yang sering diakses dan identifikasi latar belakang pemustaka.

Kedua penelitian Maryati, Yoganingrum, and Sihombing (2016) yang menjelaskan bahwa lembaga penelitian yang memiliki Pusat Dokumentasi dan Informasi (Pusdokinfo) harus memperhatikan format dan konten produk kemas ulang informasi. Lembaga riset harus membuat kebijakan tentang kemas ulang informasi yang mudah dipahami, berbasis solusi, dan disajikan secara komprehensif. Untuk itu, salah satu cara untuk membuat kebijakan kemas ulang informasi adalah pembuatan peta sains (science mapping) berbentuk dokumen policy brief menggunakan metode bibliometrik dan tersaji secara visual dalam bentuk peta 2 dimensi.

Ketiga penelitian dari Radhakrishnan and Francis (2017) mengenai proses kemas ulang yang dilakukan di Naval Physical and Oceanographic Laboratory (NPOL). Konten kemasan informasinya bersumber dari hasil penelitian dan pengembangan di bawah the Defence Research and Development Organization (DRDO), Ministry of Defence, India. Lembaga ini telah melakukan beberapa strategi pengemasan ulang informasi, di antaranya memeriksa konten informasi dari produk kemasan organisasi berdasarkan permintaan dan preferensi pengguna, mengembangkan aplikasi pengemasan ulang informasi melalui uji laboratorium dan karakteristik pencari informasi, dan membuat media pembelajaran bagi perpustakaan dalam meningkatkan peran diseminasi informasi hasil penelitian ke pemustaka yang lebih luas.

Keempat penelitian Okike (2020) yang menjelaskan bahwa pustakawan memiliki peran penting dalam penyebaran informasi terkait Covid-19 ke pemustaka melalui berbagai saluran media virtual (online). Pustakawan harus dapat menjangkau pemustaka yang lebih luas berdasarkan kebutuhan informasi yang relevan sesuai kondisi terkini. Pustakawan di era new normal dapat menyediakan pelayanan informasi digital dalam berbagai format dan jenis secara online kepada pemustaka, melalui database koleksi khusus, notifikasi teks atau Short Message Service (SMS), QR kode, layanan referensi online, media sosial, website lembaga, milis, dan katalog online 
perpustakaan atau Online Public Access Catalog (OPAC).

Berdasarkan 4 penelitian terdahulu di atas, penelitian ini memiliki persamaan penelitian mengenai kemas ulang informasi di perpustakaan atau lembaga dokumentasi, penelitian, dan informasi. Okoroma (2014) dan Okike (2020) memiliki kesamaan dengan penelitian ini meneliti kemas ulang informasi di perpustakaan. Adapun Maryati, Yoganingrum, and Sihombing (2016) meneliti kemas ulang informasi di lembaga Pusat Dokumentasi dan Informasi (Pusdokinfo) dan Radhakrishnan and Francis (2017) meneliti kemas ulang informasi di lembaga penelitian.

Penelitian ini memiliki perbedaan dengan 4 penelitian terdahulu dalam implementasi kemas ulang informasi di perpustakaan. Perpustakaan dapat mempraktikkan kegiatan kemas ulang informasi sebagai kekhasan produk perpustakaan dan profesionalitas pustakawan. Untuk itu, penelitian ini memberikan desain baru bagi pustakawan di perpustakaan dalam menghadapi era new normal. Dengan demikian, penelitian ini bertujuan untuk mengetahui strategi kemas ulang informasi untuk peningkatan pelayanan perpustakaan di era new normal melalui analisis aspek strategi dan perancangan strategi pengemasan ulang informasi digital.

\section{METODE PENELITIAN}

Peneliti dalam penelitian ini menggunakan pendekatan kualitatif dengan metode penelitian studi literatur. Peneliti melalui studi literatur dapat mengembangkan konseptualisasi, kategorisasi, dan deskripsi fenomena yang sedang diteliti (Rijali, 2018).
Konseptualisasi permasalahan dan pembahasan dapat dilakukan peneliti melalui penafsiran dan analisis data, baik mengacu pada literatur yang relevan dan pengalaman peneliti (best practice). Analisis dan penafsiran data kualitatif dilakukan dengan memperhatikan beberapa hal, di antaranya natural setting (latar alamiah), pengungkapan makna dari sudut pandang subjek penelitian, holistik dan tidak dapat dilakukan pemisahan sehingga terlepas dari konteksnya, dan instrumen utama untuk mengungkapkan makna yang terikat nilai dan konteks (Rijali, 2018).

Penelitian ini dalam teknik pengumpulan data bersumber dari sumber literatur dan best practice peneliti. Sumber literatur disebut sebagai sumber tertulis yang dapat digunakan sebagai sumber primer. Penelitian ini menggunakan sumber primer dari 4 penelitian terdahulu, antara lain Okoroma (2014); Maryati et al. (2016); Radhakrishnan and Francis (2017); dan Okike (2020). Adapun best practice peneliti atau sumber sekunder disebut juga sebagai catatan metodologis, pengalaman peneliti mengenai fenomena yang sedang dikaji (Rijali, 2018).

Sumber literatur utama di atas didukung literatur lain yang relevan dan melalui best practice peneliti. Data best practice berasal dari pengetahuan, keterampilan, dan praktik terbaik peneliti dalam kegiatan kemas ulang informasi di sebuah perpustakaan lembaga riset nasional (Nashihuddin, Yudhanto, Surapermana, \& Rishardi, 2019). Data yang sudah terkumpul kemudian dianalisis secara deskriptif. Analisis data secara deskriptif digunakan untuk menggambarkan data yang telah terkumpul apa adanya, tanpa bermaksud membuat kesimpulan yang berlaku umum 
atau generalisasi (Sholikhah, 2016).

Adapun data deskriptif penelitian bersumber dari hasil sintesis literatur hasil penelitian yang relevan dengan topik penelitian dan best practice peneliti. Peneliti dalam melakukan tahapan sintesis literatur, antara lain menetapkan artikel primer penelitian, mengidentifikasi permasalahan penelitian, menganalisis informasi tentang strategi pengelolaan kemas ulang informasi, dan menginterpretasikan data ke pembahasan penelitian. Kemudian hasil sintesis tersebut dipadukan dengan best practice peneliti dalam melakukan kemas ulang informasi.

Analisis data merupakan proses mencari data melalui wawancara, catatan lapangan, dan materi lain secara sistematis. Hasil analisis data digunakan sebagai dasar penyusunan hasil pembahasan dan kesimpulan. Ketika menyajikan data, kemungkinan ada penarikan kesimpulan dan pengambilan tindakan (Rijali, 2018). Berdasarkan uraian di atas, penelitian ini dilakukan menggunakan tahapan sebagai berikut.

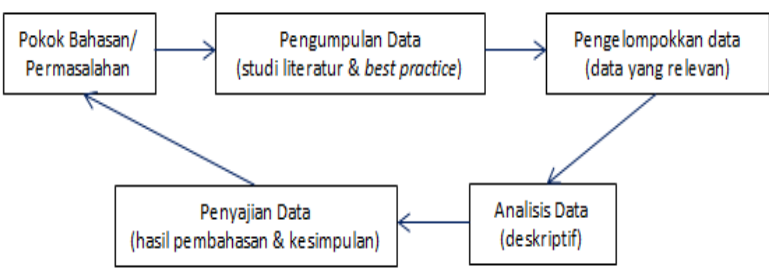

Gambar 1. Tahapan penelitian

Sumber: Hasil pengolahan data peneliti (2020)

Sesuai gambar 1, peneliti menemukan pokok pembahasan, berupa pertanyaan penelitian yang dikaji dan menjadi bahan penyajian hasil dan pembahasan. Setelah itu, peneliti mengumpulkan data yang bersumber dari sumber primer dan sekunder, di mana saling terkait untuk dilakukan interpretasi hasil penelitian. Kemudian, peneliti mengelompokkan data dan menyusun data secara sistematis berdasarkan poin-poin bahasan. Selanjutnya, peneliti melakukan analisis data secara deskriptif, yakni menggunakan interpretasi pernyataan narasi terkait pokok bahasan. Terakhir, peneliti menyajikan data berdasarkan hasil analisis deskriptif pada hasil pembahasan dan kesimpulan penelitian ini.

\section{HASIL DAN PEMBAHASAN}

Penelitian mengenai strategi kemas ulang informasi untuk peningkatan pelayanan perpustakaan di era new normal terdiri dari dua analisis, yakni aspek dan tahapan strategi kemas ulang informasi. Strategi dirancang perpustakaan untuk mencapai tujuan dan target tertentu. Untuk itu, perpustakaan memerlukan strategi untuk mengantisipasi adanya perubahan paradigma (paradigm shift) dalam pelayanan perpustakaan akibat perkembangan teknologi informasi, perubahan perilaku informasi, dan peningkatan kebutuhan informasi pemustaka yang semakin kompleks (Oyadonghan, Eke, \& Fyneman, 2016).

Okoroma (2014) mengatakan bahwa strategi dalam kemas ulang informasi diperlukan untuk memanfaatkan sumber daya informasi secara maksimal dan membuat inovasi pelayanan yang berbasis biaya. Untuk itu, perpustakaan hendaknya menetapkan strategi pengemasan ulang informasi dengan memperhatikan beberapa aspek. Pertama, kemudahan, artinya kemasan informasi lebih mudah dibaca dan dimengerti isi berdasarkan karakteristik pengguna. Kedua, format informasi yakni informasi produk kemasan berupa hasil format ulang dan sintesis informasi dari berbagai sumber informasi. Ketiga, kemutakhiran informasi, di mana informasi yang 
disajikan bersifat mutakhir dari berbagi subjek keilmuan. Keempat, transfer pengetahuan yakni memberikan pengetahuan baru bagi penggunanya (Okunade, 2015).

Analisis pertama penelitian ini mengenai aspek strategi kemas ulang informasi berupa aspek substansi yang terkait nilai informasi di setiap produk kemasan antara lain sumber informasi kemasan, jenis produk kemas ulang informasi, dan metode pengemasan ulang informasi. Pertama, aspek substansi sumber informasi kemasan yang dijadikan bahan baku atas dasar prinsip dapat diproduksi ulang dalam berbagai bentuk digital dan dapat akses secara online menggunakan komputer atau smartphone, seperti e-dictionary, e-newspaper, e-magz, atau e-maps sesuai kebutuhan pemustaka era new normal (Khoir, 2018). Sumber informasi lainnya di antaranya karya tulis artikel surat kabar/koran, majalah/tabloid, blog/web, dan karya tulis ilmiah.

Kumpulan karya tulis ilmiah (hasil penelitian) sebagai bahan kemas ulang informasi, di mana konten informasi dapat didesain dalam format yang lebih menarik dan tepat sasaran berdasarkan kebutuhan pemustaka (Pebrianti, 2015). Konten produk kemasan informasi pun dapat berupa karya terjemahan dari bahasa asing ke bahasa Indonesia (Muzaki, 2017). Karya lainnya adalah kumpulan bibliografi dan buku direktori yang disusun secara sistematis, biasanya disusun alfabetis yang dikelompokkan berdasarkan bidang/topik informasi yang sifatnya lebih spesifik (Nashihuddin \& Tupan, 2016).

Kedua, aspek substansi jenis produk kemas ulang informasi. Jenis produk kemasan informasi dapat berupa: (1) media audio visual, seperti Audio Video cassette, CD interaktif, VCD, DVD (Magfirah, 2019); (2) brosur, leaflet, spanduk, pathfinder (jejakan pustaka), serta video dokumenter (Muchlis, 2017); (3) teater populer, drama, mendongeng, kumpulan lagu, dan podcast (Dongardive, 2013); (4) karya terjemahan (tulis dan audio), grafik, model, koleksi braille, dan data hasil ekstraksi (Okike, 2020); (5) produk kemasan informasi dengan nama khusus dari lembaga, seperti paket informasi teknologi, informasi kilat, pohon industri, panduan usaha, tinjauan literatur, fokus informasi indonesia, dan film animasi (Tupan \& Nashihuddin, 2015); (6) science mapping (visualisasi pengetahuan berdasarkan tema) yang diperoleh menggunakan teknik scientometric, bibliometrik (bibliometric), webometric, dan informetric (Maryati, Yoganingrum, \& Sihombing, 2016); (7) karya hasil alih media dari publikasi yang sudah terbit, seperti buku, prosiding, jurnal, brosur, newsletter, abstrak, indeks, majalah, bibliografi, direktori, buku panduan, dan katalog koleksi.

Ketiga, aspek substansi metode pengemasan ulang informasi. Beberapa metode yang dapat diterapkan dalam pembuatan kemas ulang informasi harus disusun secara sistematis. Okunade (2015) menyebutkan di antaranya (1) penyiapan ringkasan, berisi informasi terseleksi yang disiapkan ahli informasi; (2) analisis ringkasan, mengacu pada target pengguna, konten informasi, anggaran, dan siklus hidup informasi, di mana deskripsi ringkas produk kemasan informasi berdasarkan topik yang diminati pengguna; (3) desain kemasan sesuai kriteria pengguna; (4) desain produk kemasan yang menarik sesuai permintaan pengguna (rancangan dan ukuran); (5) produksi kemasan informasi selalu 
diperiksa tahap akhir sebelum digandakan dan dilakukan diseminasi; (6) perencanaan sistem umpan balik. Metode pengemasan ulang informasi ini dilakukan untuk mengetahui keberhasilan pemanfaatan suatu produk kemas ulang informasi. Untuk itu, perpustakaan perlu menetapkan metode pengemasan ulang informasi dengan memperhatikan aspek pengorganisasian, komunikasi, dan diseminasi (Okike, 2020).

Aspek pengorganisasian, merujuk pada fungsi pengemasan ulang informasi, di antaranya alat penyimpan informasi (preservasi), penyortir informasi agar sistematis dan selektif, sarana pengiriman informasi yang lebih luas, alat terjemahan, peluang untuk menginformasikan hasil penelitian secara praktis, dan sarana promosi informasi ke masyarakat. Selain itu, perpustakaan dalam aspek ini harus mengidentifikasi latar belakang pemustaka.

Aspek komunikasi, mengacu pada strategi komunikasi dan diseminasi informasi. Fatkhah, Winoto, and Khadijah (2020) mengatakan bahwa komunikasi membantu penyampaian pesan kepada audiens dan audiens mendapatkan manfaat. Untuk itu, pustakawan dalam aspek komunikasi harus berfokus pada empat hal, antara lain partisipasi dan keterlibatan pemustaka dalam memanfaatkan produk, meningkatkan komitmen dalam penyediaan produk yang berkualitas, membangun kerja sama dengan pemustaka, dan replikasi produk dalam memaksimalkan pemanfaatan produk. Adapun strategi komunikasi dalam kegiatan diseminasi informasi adalah metode manual melalui kontak langsung (tatap muka) dan elektronik (digital) menggunakan multimedia broadcast dan perangkat internet yang tertera pada tabel 1.

Tabel 1

Metode diseminasi kemas ulang informasi

\begin{tabular}{|c|c|c|c|}
\hline No & Metode & Contoh & $\begin{array}{l}\text { Media } \\
\text { strategis }\end{array}$ \\
\hline 1 & $\begin{array}{l}\text { Kontak } \\
\text { langsung }\end{array}$ & $\begin{array}{l}\text { Kontak } \\
\text { fisik, } \\
\text { diskusi } \\
\text { fisik, } \\
\text { pengiriman } \\
\text { sumber } \\
\text { informasi } \\
\text { langsung }\end{array}$ & $\begin{array}{l}\text { Demonstrasi } \\
\text { efektif, } \\
\text { penandaan } \\
\text { dan } \\
\text { pelabelan, } \\
\text { penampilan } \\
\text { terbaik }\end{array}$ \\
\hline 2 & $\begin{array}{l}\text { Multimedia } \\
\text { broadcast }\end{array}$ & $\begin{array}{l}\text { Teks, } \\
\text { gambar, } \\
\text { suara, } \\
\text { video, } \\
\text { animasi }\end{array}$ & $\begin{array}{l}\text { Televisi, } \\
\text { radio, flyer, } \\
\text { buletin, papan } \\
\text { iklan } \\
\text { (billboard) }\end{array}$ \\
\hline 3 & Internet & $\begin{array}{l}\text { Teks, } \\
\text { gambar, } \\
\text { suara, } \\
\text { video, } \\
\text { animasi }\end{array}$ & $\begin{array}{l}\text { Telekonferens } \\
\text { i/webinar, } \\
\text { konferensi } \\
\text { suara/video, } \\
\text { email, grup } \\
\text { diskusi, sosial } \\
\text { media (blog, } \\
\text { twitter, } \\
\text { Tumblr, } \\
\text { facebook, dsb.) }\end{array}$ \\
\hline
\end{tabular}

Sumber: Okike, 2020

Strategi komunikasi dapat efektif pada perpustakaan dan pusat informasi yang hanya menyediakan pelayanan kemas ulang informasi. Selain itu, perpustakaan dan pusat informasi harus memastikan sasaran pengguna kemas ulang informasi ini. Radhakrishnan and Francis (2017) menyatakan bahwa ini terkait metode komunikasi yang dilakukan saat diseminasi informasi.

Analisis kedua dari penelitian ini adalah tahapan strategi kemas ulang informasi. Kemas ulang informasi merupakan salah satu upaya lembaga dalam peningkatan brand pelayanan 
informasi perpustakaan. Perpustakaan di lembaga penelitian/pendidikan dapat menyediakan paket informasi dan pengetahuan dalam berbagai format yang berdesain interaktif dan menarik sesuai kebutuhan informasi pemustaka, kebijakan organisasi, atau kreativitas pustakawan. Maka, perpustakaan dan pustakawan perlu melakukan beberapa tahapan sebelum menetapkan strategi pengelolaan kemas ulang informasi digital.

Tahapan pertama, perpustakaan melakukan identifikasi kebutuhan informasi pemustaka. Pemustaka di era new normal, ingin mendapatkan sumber informasi yang lengkap, praktis, dan mutakhir tanpa harus datang ke perpustakaan secara fisik. Untuk itu, perpustakaan harus merespons kebutuhan informasi pemustaka melalui pelayanan digital menggunakan sistem online dan membuat produk kemas ulang informasi digital.

Adapun pustakawan di era new normal, dapat menyediakan pelayanan paket informasi dalam format digital. pemustaka dapat mengakses secara online, melalui database koleksi khusus, notifikasi teks atau Short Message Service (SMS), QR kode, pelayanan referensi online, media sosial, website lembaga, milis, dan katalog online perpustakaan (Okike, 2020). Perpustakaan diharapkan mampu mengidentifikasi pemustaka secara strategis dan kebutuhan informasi secara spesifik, termasuk biaya akses informasinya yang berbayar atau gratis (Okoroma, 2014). Perpustakaan dapat mengetahui pemustaka yang strategis melalui penjajakan kerja sama dan kemitraan (partnership) dengan institusi perpustakaan lain, lembaga pendidikan, lembaga riset, industri, lembaga swadaya masyarakat, dan organisasi lain yang berkepentingan.

Pemustaka secara umum dapat diketahui melalui survei kebutuhan informasi pengunjung perpustakaan dan masyarakat umum. Pemustaka mengisi formulir survei mengenai profil pengguna (nama, instansi, profesi, tujuan) dan kebutuhan informasi produk kemas ulang informasi (subjek/topik, format, jenis, media penyimpanan, target pemakaian). Pustakawan setelah mendapatkan hasil dari formulir survei, lalu mengidentifikasi untuk ditindaklanjuti sesuai profiling lembaga untuk melihat kecukupan sumber daya informasi dari lembaga pemustaka. Jika sumber daya informasi lembaga pengguna cukup, perpustakaan akan melakukan bimbingan teknis saja sesuai kebutuhan jasa kemas ulang informasi dari sumber informasi yang dikelolanya. Apabila belum memiliki sumber daya informasi yang memadai, perpustakaan harus menawarkan akses kerja sama database informasi yang dilanggan dan menawarkan jasa kemas ulang informasi sesuai kebutuhan pemustaka.

Tahapan kedua, perpustakaan melakukan menyeleksi informasi untuk menentukan bahan baku (sumber informasi), subjek informasi, judul kemasan informasi, dan format kemas ulang informasi. Perpustakaan melakukan kegiatan seleksi informasi secara kolektif dan berkoordinasi dengan tim pembuat. Jika memungkinkan, pihak perpustakaan melibatkan pemustaka potensial (lembaga mitra) untuk membantu seleksi informasi.

Pada prinsipnya, kegiatan seleksi informasi dilakukan atas dasar partisipasi bersama. Untuk itu, pustakawan sebagai manajer informasi perpustakaan diharapkan dapat melakukan Selective Dissemination of Information (SDI) 
berdasarkan Current Awareness Services (CAS), melakukan analisis dan konsolidasi informasi dengan spesialis informasi/ subject specialist, mencetak ulang (reprint) produk kemas ulang informasi terdahulu untuk update informasi disertai informasi terbaru secara ringkas, melakukan penyesuaian, pengurangan, dan pengumpulan bahan khusus (seperti abstrak, bibliografi, data ekstraksi) setelah ada evaluasi pemanfaatan produk kemas ulang informasi (Dongardive, 2013). Kerja sama tim sangat dibutuhkan dalam pengemasan informasi untuk penyeleksian sumber informasi yang diperlukan.

Tahapan ketiga, pengembangan kegiatan produk kemas ulang informasi. Hal ini dimulai dari perencanaan, pembuatan, pelayanan, dan diseminasi produk kemas ulang informasi. Perpustakaan dalam kegiatan perencanaan memfokuskan pada kerja sama tim dan meningkatkan kualitas kinerja lembaga secara kolektif sesuai kurun waktu tertentu, misalnya 1 tahun. Adapun perpustakaan dalam proses pembuatan kemas ulang informasi fokus pada jenis produk kemas ulang informasi, yang tercantum dalam dokumen petunjuk teknis jabatan fungsional pustakawan. Hal ini berupa lembar lepas, paket informasi sederhana, dan literatur sekunder (seperti bibliografi, indeks, abstrak, dan direktori). Selain itu, perpustakaan pun berfokus melakukan penjajakan kerja sama dalam pelayanan berbasis korporasi kemitraan dengan lembaga pendidikan, lembaga riset, dan industri (kecil, menengah, besar) untuk meningkatkan nilai tambah produk kemasan informasi yang bersifat strategis.

Perpustakaan pada kegiatan diseminasi informasi mengoptimalkan jaringan media sosial, media broadcast, dan webinar dalam mempromosikan produk kemas ulang informasi dan meningkatkan reputasi lembaga. Perpustakaan menggunakan media ini untuk mengetahui berbagai respons dari follower dan peserta konferensi terhadap produk kemas ulang informasi yang disajikan. Bagi perpustakaan, setiap respons dari pemustaka akan memperoleh manfaat untuk meningkatkan kualitas dan kuantitas dari aspek tema/judul, format, dan konten produk kemas ulang informasi.

Tahapan keempat ialah membuat jadwal publikasi produk kemas ulang informasi terbaru. Perpustakaan membuat program kreatif dalam pemberdayaan informasi melalui kegiatan kemas ulang informasi melalui publikasi website dan media sosial perpustakan yang berisi nama proyek, jadwal, petugas layanan, dan jadwal kegiatan. Perpustakaan menyusun jadwal kegiatan (timeline) secara rinci, berisi nama produk kemasan, proses pembuatan, metode, waktu pembuatan, dan sasaran pengguna. Selain itu, perpustakaan menyusun jadwal kegiatan secara berkala setiap tahun dengan menyebutkan waktu pelaksanaan dan target kinerja setiap bulan agar perpustakaan dapat memonitor dan mengevaluasi proses dan hasil publikasi produk kemas ulang informasi secara berkala.

Produk kemas ulang informasi di perpustakaan sangat membantu pemustaka dalam merancang kegiatan pembelajaran, penelitian berbasis isu, dan informasi mutakhir. Untuk itu, perpustakaan diharapkan dapat memublikasikan materi kemas ulang informasi yang terkait dengan data publikasi Covid-19, yang dikemas dalam bentuk peta pengetahuan (science mapping), dokumen kebijakan (policy brief/policy 
paper), berisi ringkasan/abstrak (pathfinder), dan paket informasi terseleksi (artikel jurnal, dokumen peraturan, panduan/protokol kesehatan). Selain itu, lembaga riset perlu menetapkan metode pengemasan dan bentuk paket kemas ulang informasi science mapping secara tepat yang mengacu pada kebijakan lembaga dalam diseminasi informasi ke pengguna (Maryati et al., 2016).

Tahapan kelima, perpustakaan membangun komunikasi dan koneksi digital dengan pemustaka secara berkesinambungan. Komunikasi merupakan kunci keberhasilan dalam pemanfaatan produk kemas ulang informasi ke pemustaka. Untuk itu, pustakawan harus mampu berkomunikasi menggunakan bahasa umum dan mempresentasikan diri secara menarik (visualisasi, cerita, contoh) sehingga mudah dipahami pemustaka.

Perpustakaan dalam diseminasi produk kemas ulang informasi dituntut memberikan kontribusi sosial dan intelektual ke masyarakat (Alfiana \& CMS, 2020). Pustakawan terkait pemahaman, harus fokus saat membagikan pengetahuan baru kepada pemustaka setelah pemustaka membaca dan memanfaatkan produk kemas ulang informasi berupa format tercetak atau digital.

Perpustakaan harus memiliki komitmen dalam menggunakan media komunikasi secara konsisten saat melakukan diseminasi produk kemas ulang informasi. Pustakawan terkait tindakan, harus mampu mengidentifikasi berbagai perilaku pemustaka dalam memanfaatkan produk kemas ulang informasi. Hasil identifikasi sebagai dasar perpustakaan dalam penyediaan format dan jenis kemas ulang informasi yang diinginkan pemustaka. Kemudian, perpustakaan dalam mempromosikan dan melakukan diseminasi produk kemas ulang informasi dapat memublikasikan informasi di media sosial, telekonferensi/webinar, dan media broadcast.

Perpustakaan setelah mengetahui aspek dan tahapan strategi kemas ulang informasi, maka perpustakaan melakukan berbagai strategi kemas ulang informasi. Perpustakaan mengaplikasikan langsung strategi kemas ulang informasi, di antaranya perpustakaan memasukkan kegiatan kemas ulang informasi sebagai kegiatan unggulan perpustakaan dan pekerjaan utama pustakawan, memahami perilaku informasi pengguna digital native, melakukan promosi, diseminasi paket informasi digital menggunakan media sosial dan jaringan kerja sama, perubahan peran pustakawan sebagai social librarian dan public knowledge, dan menerapkan strategi Marketing and Public Relation (MPR). Pertama, perpustakaan memasukkan kegiatan kemas ulang informasi sebagai kegiatan unggulan perpustakaan dan pekerjaan utama pustakawan. Berdasarkan Peraturan Menteri Pendayagunaan Aparatur Negara dan Reformasi Birokrasi Republik Indonesia Nomor 9 Tahun 2014 Tentang Jabatan Fungsional Pustakawan dan Angka Kreditnya (2014) menyatakan bahwa pustakawan memiliki kegiatan utama pustakawan mengemas ulang informasi dalam kategori pelayanan perpustakaan pada pelayanan pemustaka.

Sesuai hal tersebut, pimpinan lembaga atau kepala perpustakaan harus menetapkan kemas ulang informasi sebagai program unggulan perpustakaan dan kegiatan utama pustakawan dalam menyediakan sumber referensi di 
perpustakaan. Setelah itu, lembaga harus memicu pustakawan untuk meningkatkan kinerja dan lembaga melakukan evaluasi hasil kinerja secara berkala minimal enam bulan sekali (per semester). Peneliti memberikan contoh penerapan kegiatan kemas ulang informasi sebagai target kinerja lembaga sesuai pengalaman (best practice) di Pusat Dokumentasi dan Informasi Ilmiah-Lembaga Ilmu Pengetahuan Indonesia (PDII - LIPI) pada gambar 2.

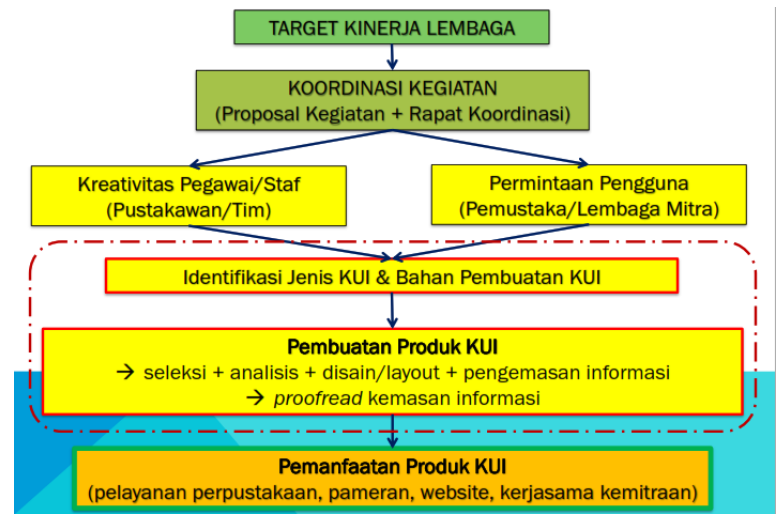

Gambar 2. Best practice peneliti dalam kemas ulang informasi

Sumber: Hasil pengolahan data peneliti, 2020

Berdasarkan gambar 2, terlihat bahwa ada beberapa tahapan dalam pengemasan ulang informasi sebagai target kinerja lembaga, khususnya di perpustakaan. Pelaksana utama kegiatan ini adalah pustakawan yang berkolaborasi dengan peneliti dan staf administrasi yang lain. Pustakawan sebagai koordinator kegiatan yang merumuskan konsep pembuatan produk kemas ulang informasi, mulai dari penyusunan proposal kegiatan hingga penyelenggaraan rapat koordinasi kegiatan. Pustakawan dalam menyusun proposal kegiatan kemas ulang informasi berdasarkan kreativitas atau permintaan pemustaka/lembaga mitra dengan mengetahui terlebih dahulu latar belakang pembuatan proposal. Kemudian pustakawan mengidentifikasi produk kemas ulang informasi yang akan dibuat sesuai bahan seleksi dan analisis informasi yang relevan dengan topik/judul kemasan, misalnya dari literatur jurnal, laporan penelitian, makalah/prosiding, koleksi standar/paten, data set, berita, dan media massa yang mengacu pada kebaruan isu dan permintaan pemustaka. Kegiatan kemas ulang informasi intinya memiliki dua kegiatan utama, antara lain pengemasan ulang dan pemrosesan ulang yang dimulai dari kegiatan seleksi, analisis, desain/layout, pengemasan, dan proofread isi kemasan informasi sebelum dicetak dan digandakan. Setelah produk kemasan informasi dibuat, langkah berikutnya adalah pemanfaatan produk kemas ulang informasi ke pemustaka melalui pelayanan perpustakaan, pameran, publikasi website/media sosial, atau kerja sama kemitraan.

Pustakawan dalam kegiatan pelayanan harus memperhatikan dua hal. Hal pertama, aspek pelayanan teknis ketika produk kemas ulang informasi dimanfaatkan untuk koleksi literatur sekunder, bahan analisis pembuatan publikasi (KTI), dan/atau laporan kegiatan lembaga yang bersifat administratif. Hal kedua, aspek pelayanan umum yang terjadi ketika produk kemas ulang informasi dilayankan kepada pemustaka, pengunjung tamu (studi banding), lembaga mitra (kerja sama), dan/atau masyarakat umum, melalui fotokopi, digandakan dengan dengan $\mathrm{CD} /$ external hard disk, publikasi melalui website (dibaca/download), atau berlangganan.

Strategi kemas ulang informasi kedua adalah pemahaman perilaku informasi pengguna digital native. Perilaku informasi ini tergantung dari cara dan kemampuan manusia dalam mengumpulkan, 
mengelola, dan memanfaatkan informasi untuk penunjang kehidupannya (Spink, 2010). Perilaku informasi setiap orang berbeda-beda karena dipengaruhi beberapa faktor. Allen, Karanasios, and Slavova (2011) menyebutkan ada 3 faktor perilaku informasi, di antaranya keinginan yang bersifat personal, rasionalitas, faktor fenomena, dan keinginan. Faktor keinginan yang bersifat personal, terkait seseorang yang mandiri dalam "menyelesaikan masalah" atau "membuat keputusan" pada kegiatan jangka pendek dengan tujuan yang jelas. Pustakawan dalam melakukan hal ini perlu mengidentifikasi perilaku pemustaka dalam konteks dan fakta yang beragam untuk membentuk cara kerja informasi yang ditawarkan.

Faktor rasionalitas, terkait kompleksitas pikiran, perasaan, dan tindakan manusia dengan informasi. Perilaku informasi bersifat sangat rasional, meskipun tidak selalu benar. Perilaku informasi berorientasi pada pengambilan keputusan dan dapat digunakan dalam membuat penilaian yang relatif sederhana terhadap perilaku individu.

Faktor fenomena, ialah faktor dalam kegiatan di luar pekerjaan atau tugas pendidikan, literasi informasi, dan sebagainya. Perilaku informasi berfokus pada kegiatan pembelajaran dan pendidikan, informasi kesehatan, dan hobi seseorang. Faktor keinginan, ialah rasa antusias individu mendapatkan informasi.

Berdasarkan beberapa faktor perilaku informasi di atas, maka pustakawan harus siap melayani pemustaka dari kalangan digital native. Kalangan ini adalah pemustaka yang tergantung pada teknologi digital (internet dan smartphone) dalam mendapatkan sumber informasi perpustakaan. Era new normal menuntut pustakawan untuk menyesuaikan kebutuhan informasi digital native, termasuk menyediakan produk kemas ulang informasi digital, dalam bentuk buku tiga dimensi (3D), pathfinder digital, infographic, video animasi, dan mutimedia.

Strategi kemas ulang informasi ketiga ialah promosi dan diseminasi paket informasi digital melalui media sosial dan jaringan kerja sama. Diseminasi informasi memiliki beberapa keuntungan di antaranya menghemat bahan baku dan biaya cetak produk kemas ulang informasi berupa file digital, mempermudah promosi ke pemustaka dalam jangkauan yang lebih luas melalui media sosial dan website perpustakaan, dan meningkatkan aksesibilitas konten informasi paket kemasan. Perpustakaan dalam mempromosikan dan melakukan diseminasi produk kemas ulang informasi ke pemustaka banyak menggunakan media sosial, seperti Facebook, YouTube, Twitter, Instagram dan webinar. Media sosial digunakan untuk meningkatkan respons dan partisipasi pemustaka jasa perpustakaan dalam kondisi non formal terhadap produk kemas ulang informasi yang dibagikan ke publik. Kegiatan diseminasi informasi dapat dilakukan melalui pameran produk kemas ulang informasi digital dan penjajakan kerja sama dengan lembaga mitra yang berkepentingan. Pustakawan pun dapat menerbitkan produk kemas ulang informasi pada website perpustakaan sebagai kegiatan promosi ke pemustaka, contohnya Pemerintah Kota Pekalongan membagikan produk kemas ulang informasi melalui website e-book digital library pada gambar 3 . 
Website ini memuat informasi koleksi tentang "Pekalongan" dalam berbagai aspek kehidupan budaya, sosial, politik, ekonomi, sejarah, dan keagamaan berupa buku digital tiga dimensi. Pemustaka untuk memanfaatkan koleksi buku digital dapat membacanya secara online, namun pemustaka belum bisa mengakses secara bebas saat memperoleh data (download) dan mencetak koleksi (print).

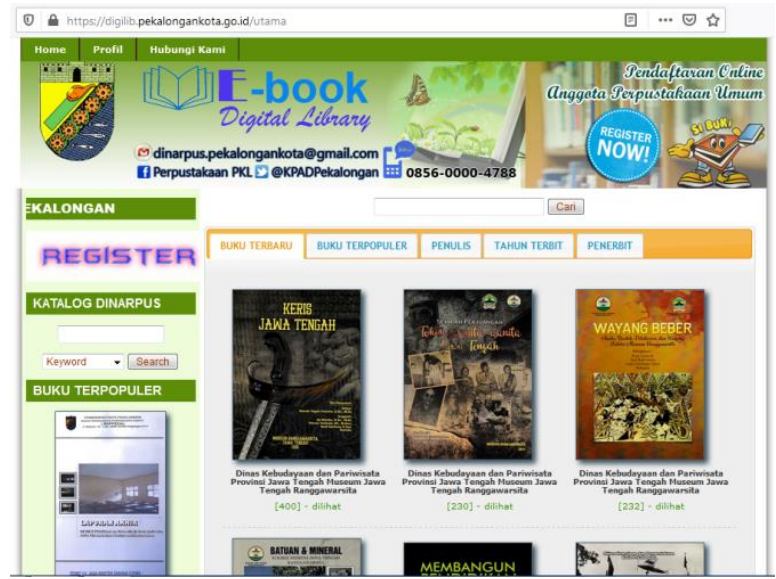

Gambar 3. Website e-book digital library

Sumber: Kantor Perpustakaan dan Arsip Daerah Kota Pekalongan, 2021

Pada gambar 4, terdapat tampilan lengkap salah satu buku dalam format tiga dimensi dari e-book digital library pemerintah Kota Pekalongan. Pemustaka melalui buku digital ini dapat membacanya secara online dengan cara membaca daftar isi buku (table of contents) hingga membuka per halaman buku.

Strategi kemas ulang informasi keempat ialah perubahan peran pustakawan sebagai social librarian dan public knowledge. Pustakawan harus memiliki jiwa sosial dan kepedulian yang tinggi terhadap sesama, khususnya pemustaka dan lembaga mitra yang menjalin kerja sama dengan perpustakaan. Sebagaimana dikatakan Wasike (2013) bahwa pustakawan harus memberikan pelayanan informasi yang terbaik bagi pemustaka.

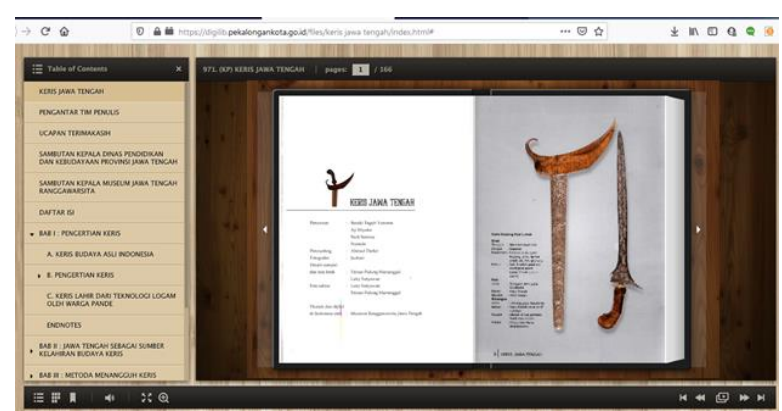

Gambar 4. Tampilan buku berjudul "Keris Jawa Tengah"

Sumber: Kantor Perpustakaan dan Arsip Daerah Kota Pekalongan, 2021

Untuk itu, pustakawan harus mulai menggeser peran dari penyedia informasi (information provider) ke pencipta pengetahuan (knowledge creator) dalam pembelajaran, pendidikan, penelitian di dalam dan luar perpustakaan. Pustakawan harus memosisikan dirinya sebagai ilmuwan (a scientist). Adapun cita-cita seorang ilmuwan dalam karier akademis yaitu menemukan teori baru (new theory finding) yang diharapkan dapat memberikan kontribusi nyata dalam pengembangan ilmu pengetahuan. Hal ini dapat berasal dari pengetahuan individu (Mahendra, 2017).

Untuk itu, pustakawan dapat berperan sebagai social librarian dan public knowledge dengan menyiapkan program kemas ulang informasi untuk kepentingan komunitas, misalnya taman bacaan masyarakat, komunitas pegiat literasi, komunitas riset bidang ilmu tertentu, dan komunitas seni dan budaya. Pustakawan dapat berperan sebagai fasilitator dan koordinator kegiatan yang bertugas mengumpulkan ide dari hasil diskusi di kalangan komunitas tertentu. Kemudian hasil diskusi dibuat konsep dan kerangka analisis informasi untuk dikembangkan bersama. Pustakawan pun sebagai trend center pengemasan pengetahuan dalam 
produk kemas ulang informasi yang dikehendaki bersama.

Strategi kemas ulang informasi kelima adalah penerapan Marketing and Public Relation (MPR), sebuah strategi peningkatan penjualan produk dan citra lembaga. Marketing and public relation menekankan dua aspek, antara lain penjualan (selling) dan reputasi (reputation). Strategi marketing and public relation tidak berorientasi pada aspek profit atau keuntungan ekonomi, namun implementasi strategi ini menekankan pada pembangunan reputasi organisasi/perusahaan melalui produk dan jasa yang ditawarkan ke pelanggan/konsumen.

Pelaksanaan marketing and public relation memiliki prinsip saling pengertian (mutual understanding) antara produsen dan konsumen. Abdillah (2017) menuliskan bahwa strategi marketing and public relation bertujuan memberikan informasi, pendidikan, dan upaya peningkatan pemahaman masyarakat melalui pengetahuan tentang suatu merek produk. Strategi marketing and public relation dapat dilakukan melalui beberapa cara, di antaranya publikasi kegiatan, membangun identitas melalui media, membuat acara (event) pada waktu yang tepat, menginformasikan berita kegiatan, mempresentasikan (pidato) strategi marketing, aktif dalam kegiatan sosial, dan memberikan dukungan sponshorsip.

Strategi marketing and public relation dalam kemas ulang informasi dapat diterapkan dengan membangun brand pelayanan perpustakaan menggunakan format, bentuk, dan tampilan produk kemas ulang informasi yang dihasilkan lembaga. Brand akan terlihat dari produk, tampilan visual, bentuk fisik, dan keterbacaan konten informasi produk kemas ulang informasi, contohnya brand produk kemas ulang informasi pada PDIILIPI adalah Pohon Industri yang dikemas dalam format digital. Pohon Industri merupakan paket informasi yang berisi skema tentang pemanfaatan suatu komoditas hewan/tumbuhan.

Pohon Industri memuat informasi yang disusun secara sistematis berdasarkan kerangka informasi yang ditetapkan tim penyusun. Sebagian besar konten informasi bersumber dari artikel jurnal nasional dan internasional yang relevan dengan topik kemasan informasi yang dibuat. Setiap bagian komoditas produk diuraikan secara sistematis dan berlandasan ilmiah. Adapun konten informasi tersusun dari bagan atau diagram alir yang menghubungkan setiap bahan komoditas utama yang dianalisis, berupa uraian penjelasan terkait manfaat dari setiap bagian komoditi yang dianalisis.

Pada gambar 5, setiap manfaat komoditas Pohon Industri menyertakan artikel lengkap sebagai rujukan bagi pemustaka. Tampilan paket kemasan Pohon Industri dibuat PDII-LIPI bekerja sama dengan Sampoerna Foundation. Setiap informasi yang tersaji, diharapkan dapat memicu pemustaka khususnya para pengusaha yang bergerak dalam Industri Masyarakat Kecil dan Menengah (UMKM) untuk mengembangkan diversifikasi produk yang bernilai ekonomi sesuai potensi daerahnya masing-masing.

Pustakawan dapat membuat produk kemas ulang informasi digital yang serupa dengan Pohon Industri ini. Pada pandemi Covid-19, pustakawan dapat menganalisis informasi dari berbagai artikel ilmiah dan populer terkait Covid-19. Kemudian pustakawan menyeleksi informasi, menganalisis, dan menyintesis format dan 
kerangka yang telah ditetapkan menggunakan skema bagan, infographic, atau model lainnya.

Pada prinsipnya, perpustakaan dalam membuat brand pelayanan kemas ulang informasi harus peka terhadap isu yang sedang berkembang di masyarakat. Selain itu, perpustakaan berdasarkan marketing and public relation harus membangun reputasi dan memastikan bahwa konten informasi dalam paket kemasan informasi telah lengkap dan mutakhir, pemustaka mudah mengakses melalui media online, dan pustakawan selalu ramah dalam memberikan pelayanan informasi.

\section{SIMPULAN}

Kepala perpustakaan di era new normal memegang peran penting dalam membuat kebijakan kemas ulang informasi sebagai bagian pelayanan perpustakaan dengan dukungan dari pustakawan terkait penentuan strategi dan kemampuan membuat paket kemas ulang informasi. Pustakawan harus memiliki kemampuan mendaur ulang informasi, mengenali jenis produk kemas ulang informasi, metode pengemasan, membuat ringkasan, dan kebutuhan pengguna. Selain itu, pustakawan menguasai alat penyimpan informasi, penyortir informasi, sarana pengiriman informasi, alat terjemahan, dan sarana promosi informasi. Untuk itu, kepala perpustakaan, pustakawan, dan pemustaka potensial melakukan koordinasi dengan tim pembuat produk kemas ulang informasi dalam mengidentifikasi kebutuhan informasi pemustaka, menyeleksi informasi, subjek informasi, judul kemasan informasi, dan format kemas ulang informasi. Setelah produk kemas ulang informasi selesai, pustakawan dapat mengembangkan produk melalui kerja sama tim menggunakan media sosial, membuat jadwal publikasi melalui program kreatif, dan mengomunikasikan secara digital kepada pemustaka. Dengan demikian, kepala perpustakaan membuat produk kemas ulang informasi sebagai kegiatan unggulan perpustakaan dan pekerjaan utama pustakawan. Pustakawan pun harus meningkatkan keahlian dalam social librarian, public knowledge, dan Strategi Marketing and Public Relation (MPR). Penelitian ini dapat dikembangkan lebih lanjut mengenai program pengembangan kompetensi khusus bagi pustakawan dalam pengelolaan pengetahuan dari berbagai jenis dan format kemas ulang informasi.

\section{DAFTAR PUSTAKA}

Abdillah, F. (2017). Efektivitas marketing public relation dalam membangun citra merek perusahaan jasa telekomunikasi. Jurnal Ecodemica, 1(1), 1-9.

https:/ / doi.org/10.31294/jeco.v1i1.15 65

Alfiana, A., \& CMS, S. (2020). Layanan kemas ulang informasi berbasis digital. PUSTABIBLIA: Journal of Library and Information Science, 4(2), 245-264.

https:/ / doi.org/10.18326/ pustabiblia .v4i2.245-264

Allen, D., Karanasios, S., \& Slavova, M. (2011). Working with activity theory: Context, technology, and information behavior. Journal of the American Society for Information Science and Technology, 62(4), 776-788. https:/ / doi.org/10.1002/asi.21441

Bello, S. A., \& Ojjo, R. F. (2018). Information repackaging services in Nigerian Public Libraries. East African 
Scholars Journal of Education, Humanities and Literature, 1(1), 30-39. https://doi.org/10.36349/easjehl.201 8.v01i01.005

Dongardive, P. (2013). Information repackaging in library services. International Journal of Science and Research (IJSR), 2(11), 204-209. Retrieved from https://www.ijsr.net/archive/v2i11/ MDIwMTM0MDM=.pdf

Fatkhah, U., Winoto, Y., \& Khadijah, U. L. S. (2020). Diseminasi informasi zero waste oleh Yayasan Pengembangan Biosains dan Bioteknologi. Jurnal Kajian Informasi \& Perpustakaan, 8(1), 49-68.

https://doi.org/10.24198/jkip.v8i1.26 615

Kantor Perpustakaan dan Arsip Daerah Kota Pekalongan. (2021). E-book digital library. Kantor Perpustakaan Dan Arsip Daerah Kota Pekalongan. Retrieved Janury 01，2020， from https:/ / digilib.pekalongankota.go.id /utama

Khoir, S. (2018). The need to change: Perilaku dan manajemen informasi dalam era normal baru. Peringatan HUT Ke-67 Perpustakaan Universitas Gadjah Mada; Universitas Gadjah Mada (UGM). Retrieved Janury 01, 2020, from

https:/ / repository.ugm.ac.id/274265

/1/Pidato Ilmiah dalam Rangka Dies 67 Perpustakaan UGM 2017.pdf

Kwok, C. S. Y., Chan, D. L. H., \& Cheung, A. S. M., \& Wong, M. K. (2014). Demand-driven acquisition at HKUST library: The new normal. Interlending $\mathcal{E}$ Document Supply, 42(4), 153-158. https://doi.org/10.1108/ILDS-092014-0046

Magfirah. (2019). Pemanfaatan teknologi informasi dalam proses kemas ulang informasi di UPT Perpustakaan Universita Hasanuddin Makassar (Skripsi) [UIN Alauddin, Makassar]. Retrieved from http://repositori.uinalauddin.ac.id/17620/1/Pemanfaatan Teknologi Informasi dalam Proses Kemas.pdf

Mahendra, I. W. E. (2017). Menemukan pengetahuan baru melalui penelitian ilmiah: Kajian singkat tentang penelitian eksperimen, ex-post facto, dan PT. Seminar Nasional Mengembangkan Kemampuan Research Dalam Menghadapi Era SDGs, 12-24. Retrieved from https://www.researchgate.net/profil e/Eka-

Mahendra/publication/341453351_M enemukan_Pengetahuan_Baru_Melal ui_Penelitian_Ilmiah/links/5ec24a639 2851c11a8704912/MenemukanPengetahuan-Baru-MelaluiPenelitian-Ilmiah.pdf

Maryati, I., Yoganingrum, A., \& Sihombing, A. (2016). Science mapping as a tool for presentation of information on the information repackaging for the policy maker. Proceedings International Conference on Science Mapping and the Development of Science, 1-8. Retrieved from https://www.researchgate.net/profil e/Ira-

Maryati/publication/315572356_Scie nce_mapping_as_a_tool_for_presenta tion_of_information_on_the_informat ion_repackaging_for_the_policy_mak er/links/5c072ec7a6fdcc315f9ddb6a/ Science-mapping-as-a-tool-forpresentation-

Peraturan Menteri Pendayagunaan Aparatur Negara dan Reformasi Birokrasi Republik Indonesia Nomor 
9 Tahun 2014 Tentang Jabatan Fungsional Pustakawan dan Angka Kreditnya. 13 Januari 2014. Jakarta. Retrieved from https://jdih.menpan.go.id/data_puu $/ 9$ final.pdf

Muchlis. (2017). Analisis kemas ulang informasi di Perpustakaan Utsman Bin Affan Universitas Muslim Indonesia (Skripsi) [UIN Alauddin Makassar, Makassar]. Retrieved from http:/ / repositori.uinalauddin.ac.id/6545/

Muzaki, M. R. (2017). Kemas ulang informasi koleksi antiquriat: Langka di Perpustakaan Arsip Nasional Republik Indonesia (ANRI) Jakarta (Skripsi) [Universitas Islam Negeri Syarif Hidayatullah, Jakarta]. Retrieved from

https:/ / repository.uinjkt.ac.id/dspac e/bitstream/123456789/36431/1/MO HAMMAD RIFQI MUZAKI FAH.pdf

Nashihuddin, W., \& Tupan, T. (2016). Manajemen layanan kemas ulang informasi digital di PDII LIPI. Lentera Pustaka: Jurnal Kajian Ilmu Perpustakaan, Informasi Dan Kearsipan, 2(2), 95-107. https:/ / doi.org/10.14710/lenpust.v2i 2.13477

Nashihuddin, W., Yudhanto, S., Surapermana, A. S., \& R. (2019). Manajemen data penelitian dengan dataverse: Best practice pustakawan menggunakan sistem repositori ilmiah nasional LIPI. Libraria: Jurnal Perpustakaan, 7(2), 331-362. https:// doi.org/10.21043/libraria.v7i 2.6508

Okike, B. I. (2020). Information dissemination in an era of a pandemic (COVID-19): Librarians' role. Library
Hi Tech News, 37(9), 1-4. https:/ / doi.org/10.1108/LHTN-042020-0040

Okoroma, F. N. (2014). Information repackaging to target groups for a fee: A strategic plan. Education Journal, $3(5)$, 308-315. https:/ / doi.org/10.11648/j.edu.20140 305.17

Okunade, B. (2015). Information repackaging and community information services: Course manual. Ibadan: University of Ibadan

Oyadonghan, J. C., Eke, F. M., \& Fyneman, B. (2016). Information repackaging and its application in academic libraries. International Journal of Computer Science and Information Technology Research, 4(2), 217-222. Retrieved from https:/ / researchpublish.com/ / uploa d/book/Information Repackaging3243.pdf

Pebrianti, Y. (2015). Kemas ulang informasi: Kumpulan karya tulis ilmiah peneliti di Lingkup Balai Penelitian Dan Pengembangan Budidaya Air Tawar (BPPBAT) Bogor. Jurnal Pari, 1(1), 27-33. https://doi.org/10.15578/jp.v1i1.131

Radhakrishnan, S., \& Francis, A. T. (2017). Information repackaging services in research and development organisations: A study with special reference to agricultural research institutions in India. Indians Journals, $7(1)$, 40-48.

https:/ / doi.org/10.5958/22777946.2017.00004.3

Rijali, A. (2018). Analisis data kualitatif. Alhadharah: Jurnal Ilmu Dakwah, 17(33), 81-95.

https:/ / doi.org/10.18592/alhadharah .v17i33.2374 
Rizkiyah, F. (2017). Produk pohon industri: Analisis kemas ulang informasi di PDIILIPI (Skripsi) [Universitas Islam Negeri Syarif Hidayatullah, Jakarta]. Retrieved from https:/ / repository.uinjkt.ac.id/dspac e/bitstream/123456789/36614/2/FA THIYATUL RIZKIYAH-FAH.pdf

Rodiyah, \& Indrakasih, R. I. (2020). Persepsi dan harapan pemustaka terhadap pengembangan sistem manajemen Perpustakaan UIN Raden Intan di era Covid 19 menuju new normal lifestyle. Jurnal Pustaka Budaya, 7(2), 113-123. https://doi.org/10.31849/pb.v7i2.417 8

Sholikhah, A. (2016). Statistik deskriptif dalam penelitian kualitatif. KOMUNIKA: Jurnal Dakwah Dan Komunikasi, 10(2), 342-362. https:/ / doi.org/10.24090/komunika. v10i2.953

Spink, A. (2010). Information behavior: An evolutionary instinct. United Kingdom: Springer. Retrieved from https:/ / www.springer.com/gp/book /9783642114960
Tupan, T., \& Nashihuddin, W. (2015). Kemas ulang informasi untuk pemenuhan kebutuhan informasi usaha kecil menengah: Tinjauan analisis di PDII-LIPI. BACA: Jurnal Dokumentasi Dan Informasi, 36(2), 109124.

https://doi.org/10.14203/j.baca.v36i2 .206

Ugwuogu, U. O. (2015). Expectations and challenges of information repackaging in Nigerian Academic Libraries. International Journal of Learning $\mathcal{E}$ Development, 5(2), 56-64. https:// doi.org/10.5296/ijld.v5i2.7514

Wasike, J. (2013). Social media ethical issues: Role of a librarian. Library $\mathrm{Hi}$ Tech News, 30(1), 8-16. https://doi.org/10.1108/07419051311 320922

Wulansari, A. (2017). Library pathfinder: Kemas ulang informasi dalam memudahkan temu kembali bagi pemustaka. Publication Library and Information Science, 1(2), 44-53. https://doi.org/10.24269/pls.v1i2.721 


\section{DAFTAR GAMBAR}

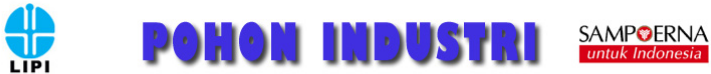

\section{KOLEKSI DIGITAL}

\section{TEKNOLOGI TEPAT GUNA}

POHON INDUSTRI
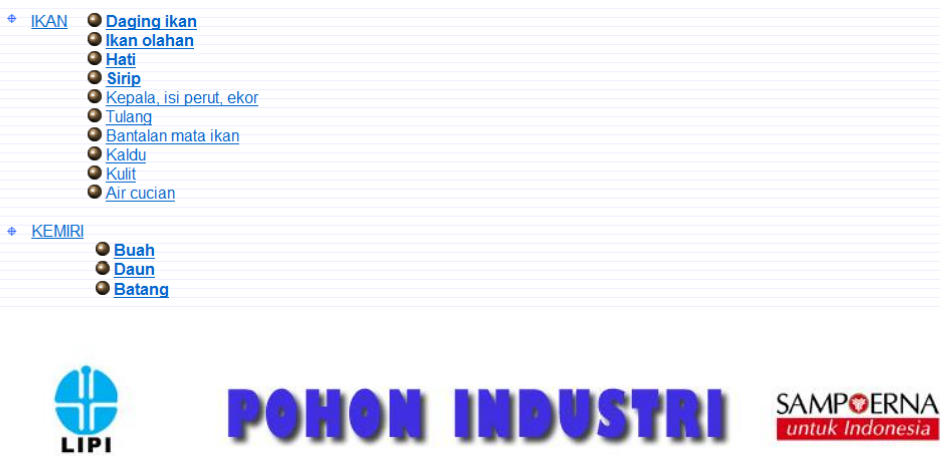

POHON INDUSTRI

IKAN

Ikan merupakan sumber protein hewani murah dan memiliki manfaat cukup besar bagi kesehatan. Melalui berbagai cara, ikan dapat diolah menjadi bermacam produk pangan, pakan ternak, dan produk untuk keperluan industri. Pembuatan pohon industri ini dimaksudkan untuk memberikan produk yang dapat dibuat dari ikan dan pemanfaatan k keperluan industri.

Diharapkan informasi ini dapat merangsang pengusaha melakukan dan mengembangkan diversifikasi produk yang bernilai tinggi.

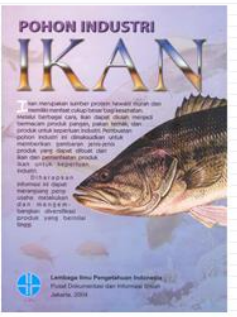

Informasi lebih lanjut hubungi : J1. Jend. Gatot Subroto 10

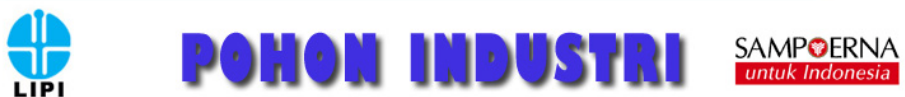

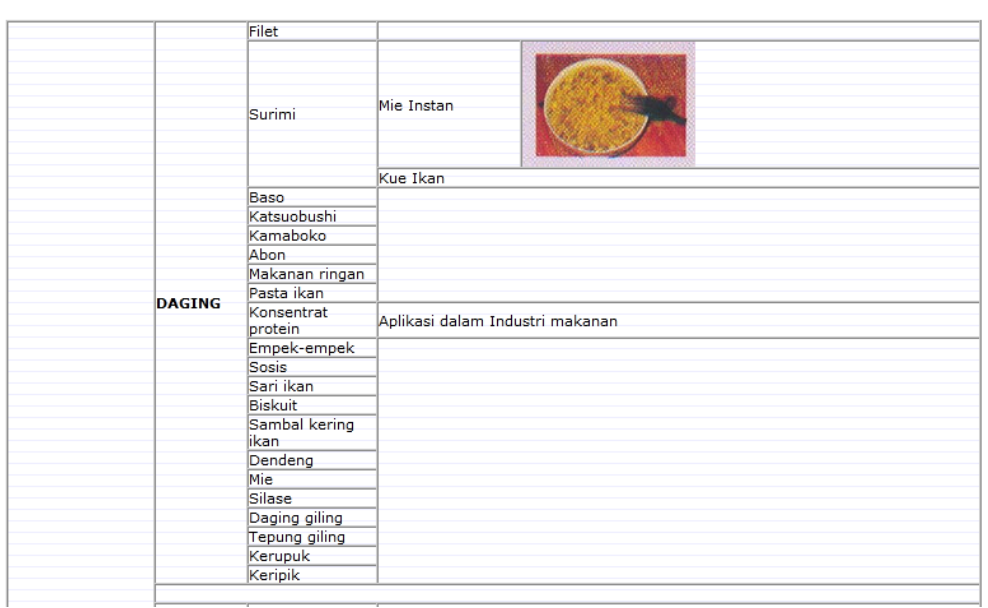

Gambar 5. Pohon industri PDII-LIPI

Sumber: Data penelitian PDII-LIPI, 2020 